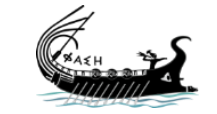

journal.phaselis.org
PHAS LLIS

Issue IV (2018)
Disiplinlerarası Akdeniz Araştırmaları Dergisi

Journal of Interdisciplinary Mediterranean Studies

\title{
Hisarçandır'dan Ele Geçen Marcus Aurelius Kamoas ve Ailesine Ait Lahit Mezar
}

\author{
The Sarcophagus of Marcus Aurelius Kamoas and His Family \\ Found in Hisarçandır
}

\section{Ahmet ÇELiK - Süleyman ATALAY - Ferhan BÜYÜKYÖRÜK}

The entire contents of this journal, Phaselis: Journal of Interdisciplinary Mediterranean Studies, is open to users and it is an 'open access' journal. Users are able to read the full texts, to download, to copy, print and distribute without obtaining the permission of the editor and author(s). However, all references to the articles published in the e-journal Phaselis are to indicate through reference the source of the citation from this journal.

Phaselis: Journal of Interdisciplinary Mediterranean Studies is a peer-reviewed journal and the articles which have had their peer reviewing process completed will be published on the web-site (journal.phaselis.org) in the year of the journal's issue (e.g. Issue III: JanuaryDecember 2017). At the end of December 2016 the year's issue is completed and Volume IV: January-December 2018 will begin.

Responsibility for the articles published in this journal remains with the authors.

Citation A. Çelik, S. Atalay - F. Büyükyörük, "Hisarçandır'dan Ele Geçen Marcus Aurelius Kamoas ve Ailesine Ait Lahit Mezar". Phaselis IV (2018) 181-198.

http://dx.doi.org/10.18367/Pha.18012

Received Date: 17.04.2018 | Acceptance Date: 30.05.2018

Online Publication Date: 27.06.2018

Editing Phaselis Research Project

www.phaselis.org 


\title{
Hisarçandır'dan Ele Geçen Marcus Aurelius Kamoas ve Ailesine Ait Lahit Mezar
}

\section{The Sarcophagus of Marcus Aurelius Kamoas and His Family Found in Hisarçandır}

\author{
Ahmet ÇELIK* - Süleyman ATALAY* ${ }^{* *}$ Ferhan BÜYÜKYÖRÜK ${ }^{* * *}$
}

\begin{abstract}
Öz: Phaselis teritoryumu içerisinde yerel işçilikli Hisarçandır Marcus Aurelius Kamoas lahdi oldukça zengin bir kompozisyon ve bezemeye sahiptir. Bazı betimlemeleriyle Pisidia geleneğini yansıtan özellikler taşımaktadır. Lahit, sanatsal özellikleri ve yazııına ek olarak döneminin modasını büyük oranda takip eden portre özellikleriyle Roma İmparatorluk Dönemi içerisinde MS III. yüzyıl ortalarına tarihlenebilir.
\end{abstract}

Anahtar sözcükler: Hisarçandır, Lahit, Girland, Tabula Ansata, Aslan, Boğa, Hayat Ağacı, Portre, Roma

Abstract: Within Phaselis territory, Marcus Aurelius Kamoas sarcophagus of local craftsmanship has a very rich composition and decoration and reflects the Pisidian tradition with some depictions. In addition to the artistic features and inscription, with the portrait features reflecting the fashion of the period in great detail, sarcophagus can be dated to the mid- II $^{\text {rd }}$ century of Roman Imperial Period.

Keywords: Hisarçandir, Sarcophagus, Garland, Tabula Ansata, Lion, Bull, Life of Tree, Portrait, Rome

\section{Giriş}

Antalya İli, Konyaaltı Illçesi, Hisarçandır Mahallesi, Cumayanı Mevkii'ndeki ${ }^{1}$ lahit teknesi ve parçalanmış durumdaki kapağı 2008 yılında Antalya Müzesi'ne taşınmıştır² (Fig. 1-3). Yerel kireçtaşından tek parça bir kayanın işlenmesi ile oluşturulmuş lahit teknesinin tek uzun yüzü ile iki kısa yüzü işlenmiş, diğer uzun yüzü kabaca tıraşlanarak boş bırakılmıştır (Fig. 4-6). Lahdin aşınmalar

* Dr., Antalya Müzesi Müdür Yrd. V., Antalya, ahmetark.celik@homail.com

** Uzm. Arkeolog, Antalya Müzesi Müdürlügüü, Antalya, slymnatalay@gmail.com

**** Arkeolog, Antalya Müzesi Müdürlüğü, Antalya, ferhanby@gmail.com

1 Phaselis teritoryumu sınırları kuzeydoğuda Hurma-Liman bölgesini içerirken kuzeybatıda Çatalçam, Çandır Asarı ve Kozağacı gibi yerleri içerisine alarak güneyde Beycik sınırlarından geçip Akdeniz'e bağlanmaktadır ve Trebenna, Onobara ve Typallia gibi yerler teritoryum sınırları dışında kalmaktadır. Phaselis kentinin sahip olduğu teritoryum sınırları ve bu sınırlar içerisinde yer alan yerleşimler için detaylıca bk. Tüner Önen 2008 25-48; Gürel 2016, 280, fig. 1; Ayrıca, Phaselis teritoryumu sınırları Kuzeyde Gökdere Vadisi'ne ulaşmakta, güneyde Üç Adalar'dan Tahtalı Dağı'na doğru çekilecek bir hat doğrultusunda devam etmekte ve batıda Çandır Vadisi boyunca uzanmaktadır, bk. Arslan et al. 2013, 224, fig. 1; Dolayısıyla Hisarçandır Lahdi'nin bulunduğu alan Phaselis teritoryumunda kalmaktadır.

2 Hisarçandır lahit teknesinin taşınması ve lahit kapağı parçalarının kurtarma kazısıyla çıkarılması çalışmaları Antalya Müzesi uzmanları Mustafa Demirel ve Ferhan Büyükyörük tarafından yürütülmüştür. Orijinal yerinde lahit teknesinin $2.55 \times 1.30$ m boyutlarında 4 parçalı bir podyum üzerinde bulunduğu, podyumunun bezemesiz sade yapıda olması, kaçakçılar tarafından tahrip edilmesi ve taşıma güçüğü nedeniyle yerinde bırakıldığı, lahit teknesinin 24-25.08.2008 tarihli çalışma ile, kapağının ise 20-21.10.2008 tarihinde yapılan kurtarma kazısı sonucu getirildiği uzman raporunda belirtilmektedir. Ayrıca lahit teknesi 2008/76, kapağı ise 2008/77 envanter numarasıyla kaydedilmiştir. 
sonucu deformasyona uğraması nedeniyle yüzeyinde bulunan figürler ve bezemeler net seçilemediğinden RTI (Reflectance Transformation Imaging) adı verilen "Yansıtma Dönüşümlü Görüntüleme" belgeleme ve analiz metodu ${ }^{3}$ kullanılmıs ve gerek ikonografik gerekse epigrafik veriler üzerinde daha net sonuçlara ulaşılmıştır ${ }^{4}$.

Lahit teknesinin uzunluğu $2.32 \mathrm{~m}$, genişliği 1.20 m, yüksekliği ise 1.47 m'dir (Fig. 2, 4, 7-8). Ön yüz merkezde yazıtlı bir tabula ansata bulunur ve üst dış kısmının iki yanında hatları zorlukla seçilebilen birer boğa başı (bukephalion) girland taşıyıcısıdır. Girland, yazıtlı tabula ansata'yı çevrele-

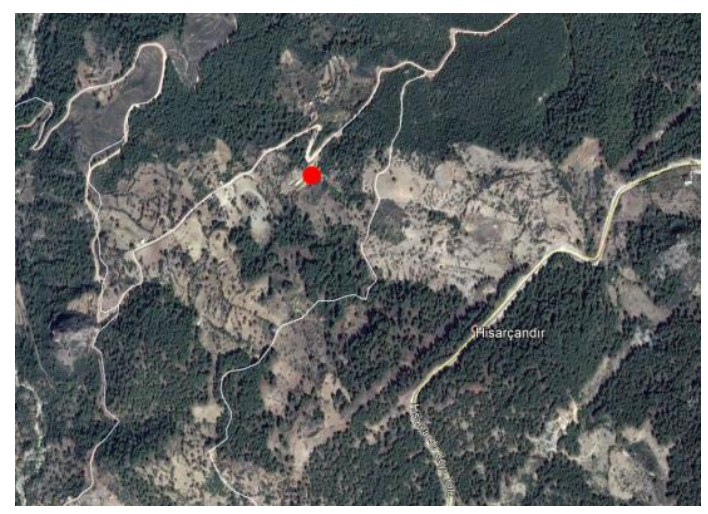

Fig. 1 Lahdin bulunduğu yaklaşık alan (Google Earth - 10.04.2018) yerek boğa başlarına tutturulmuş ve girlandın alt kısmına bir üzüm salkımı pandantif olarak asılmıştır. Girlandın sağ ve sol yanında, kalkan veya tondonun merkezine yerleştirilmiş çelenk içerisinde birer erkek ve kadın büstü bulunur. Karşıdan bakıldığında ön yüz sağ alt tarafta Eros kaplan avlarken sol alt tarafta ise aslan-boğa mücadele sahnesi yer alır. Ön yüz en altta merkezde karşılıklı duran iki aslanın sağ ve soluna doğru hayvanlar frizi görülür. Bunun dışında lahdin ön yüzünün üç yanı bir kuşak halinde asma-üzüm salkımı bezemelidir (Fig. 2).

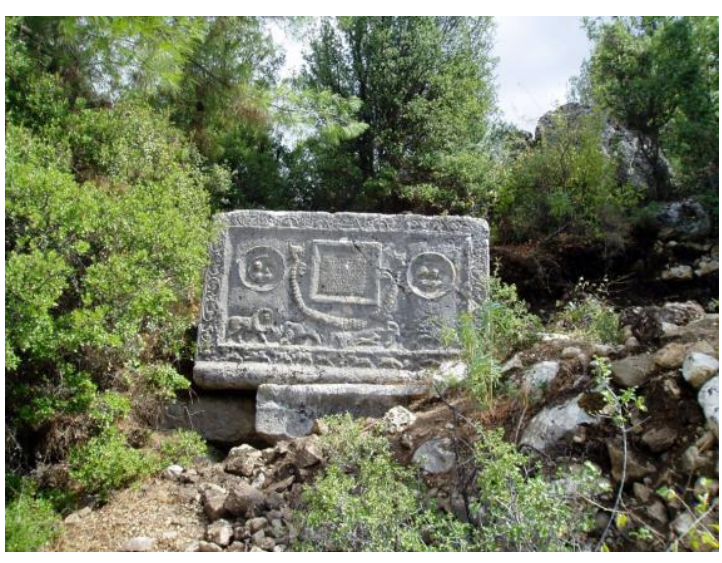

Fig. 2 Lahdin bulunduğu yaklaşık alan

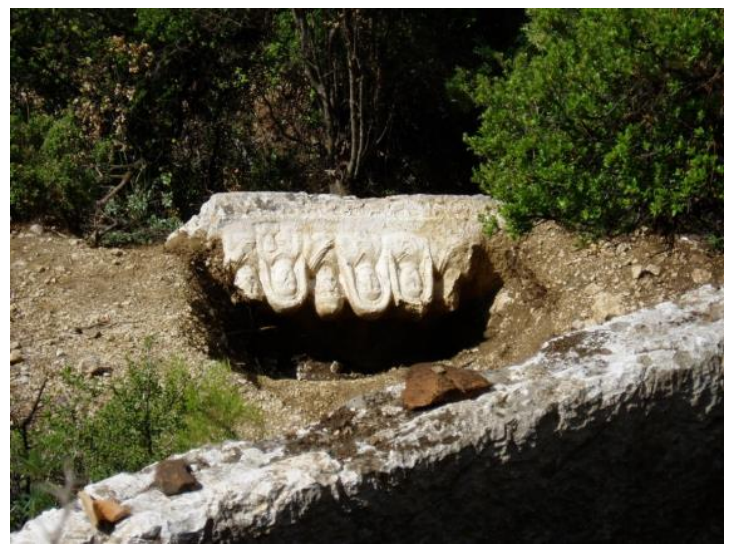

Fig. 3 Lahit teknesi ve kapağı

Hisarçandır Lahdi'nin kısa yüzlerinde 8 yapraklı açmış rozetli kalkan bulunurken sağ kalkanın altına kabzası içinde kılıç, sol kalkanın altına ise mızrak yerleştirilmiştir (Fig. 5-6). Lahit kapağııın uzunluğu 2.48 m, genişliği 1.36 m, yüksekliği ise 0.74 m’dir (Fig. 3, 5-6, 9-11). Kapağın merkezi ve köşe akroterlerinin ana hatları belirlenmiş olup, sadece ön yüzdeki akroterleri palmet motifi bezemelidir. Kapağın her iki alınlığında Gorgo Medusa başı kabartması bulunurken cepheye bakan bölümünde girland taşıyıcı boğa başları zorlukla da olsa seçilebilmektedir. Kapağın ön merkezinde 6 bireye ait yüksek kabartma büst bulunurken bir de çocuk kabartması görülmektedir.

3 RTI görüntüleme sitemine ilişkin detaylı bilgi için bk. Malzbender et al. 2001; Mudge et al. 2006; Akçay 2016, 1-16; Tüner Önen et al. 2017, 344-349.

4 Hisarçandır Lahdi'nin RTı kayıtları, Akdeniz Üniversitesi, Akdeniz Uygarlıkları Araştırma Enstitüsü, Akdeniz Eskiçağ Araştırmaları Anabilim Dalı Araştırma Görevlileri, Aykan Akçay ve Betül Gürel tarafından alınmış olup, kendilerine teşekkürlerimizi sunarız. 


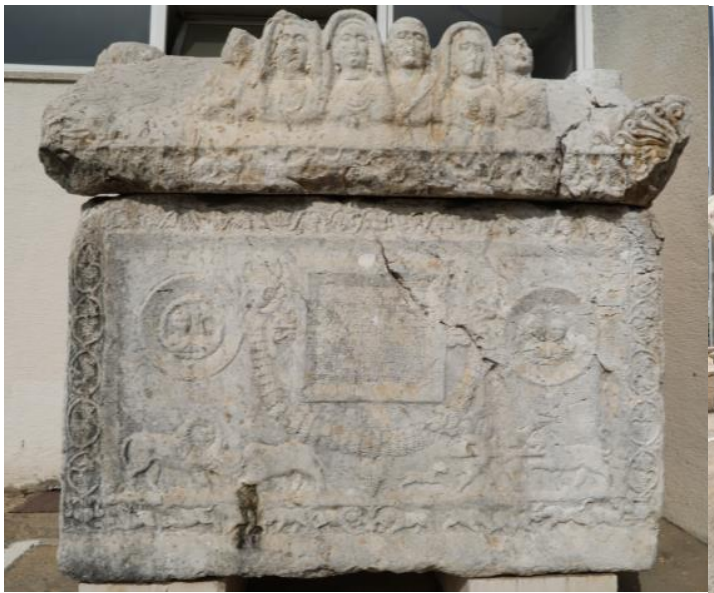

Fig. 4 Antalya Müzesi: Lahit teknesi ve kapağı

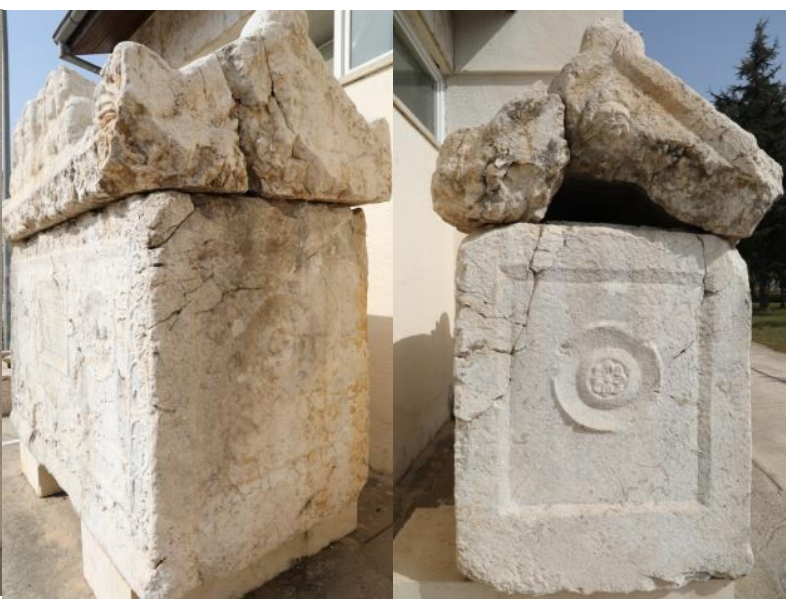

Fig. 5 Sağ yüz

Fig. 6 Sol yüz

\section{Tipoloji ve İkonografi}

Hisarçandır Marcus Aurelius Kamoas Lahdi'nin ön yüzünün merkezinde bir girland, yazıtlı tabula ansatayı çevreleyerek boğa başlarına tutturulmuş ve girlandın alt kısmına bir üzüm salkımı pandantif olarak asılmıştır (Fig. 2, 7-8). Girlandlı lahitlerin Roma İmparatorluk Dönemi içerisinde seri üretim tarihi olan MS II. yüzyıl başlarına kadar gittiği bilinmektedir. Ancak Anadolu'da, gömü geleneğiyle ilişkili olarak en azından Hellenistik Dönem'den seri üretim tarihine kadar olan bir süreçte bazı lahitlerde ya da sunaklarda girlandın kullanıldığı söylenebilir ${ }^{5}$.

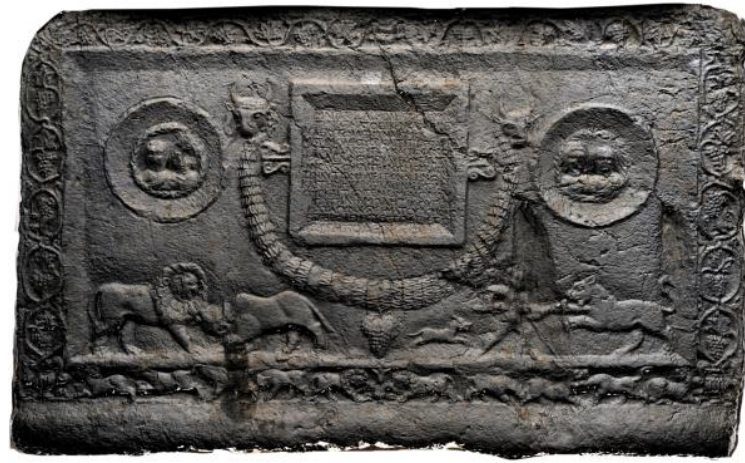

Fig. 7 Lahit teknesi ön yüz (RTI: diffuse gain)

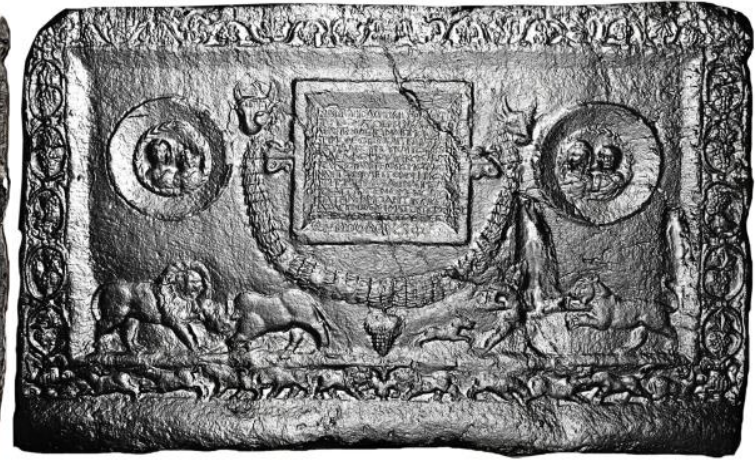

Fig. 8 Lahit teknesi ön yüz (RTI: specular enhancement)

Ön yüzün sağ ve sol yanında, kalkan veya tondonun merkezine yerleştirilmiş stilize defne yapraklı çelenk ${ }^{6}$ içerisinde birer çift erkek-kadın büstü bulunur (Fig. 8). Lahitlerde büst kullanımı MÖ IV. yüzyıl veya Hellenistik Dönem'e kadar uzanır ${ }^{7}$. Roma Dönemi lahitleri üzerinde kullanımı devam etmiş olmakla beraber kalkan veya tondo içerisinde portre büstler içeren lahitler, Antoninuslar Dönemi içerisinde MS 150-160 yıllarından itibaren görülür ve III. yüzyılda moda

5 Günümüzde Burdur sınırlarında bulunan Kibyratis Bölgesi`nde yer alan Bubon’da yapılan bir girlandlı lahdin MÖ III. veya II. yüzyılda yapıldığı düşünülmektedir, Koch 2001, 214; Seri üretim öncesi lahitlerde veya sunaklarda girland kullanımına ilişkin bk. Işık 1977, 380; 1983, 254 vd.; 1993, 9 vd.; Strocka 1996, 455 vd.

6 Mezarlarda kullanılan çelenk zaferi simgelerken ayrıca mezar sahibinin başarıları ile ödüle de işaret etmektedir, bk. Öztürk 2003, 17.

7 Buna ilişkin örnek, Hoyran'da MÖ IV. veya III. yüzyıla tarihlendirilen veya bütünüyle Hellenistik Dönem tarihli değerlendirilen iki lahit üzerinde aslan ve boğa başlarının dışında kadın büstü gösterilebilir. Özer 2014, 81; Geç Hellenistik Dönem örneği için bk. Koch 2001, 215. 
olmuştur. Bunun yanında Pamphylia Bölgesi osthoteklerinin ön yüzünde bulunan kavislerin içerisine bir kadın ve/veya bir erkeği betimleyen büstler yapılabilmektedir ${ }^{8}$. Hisarçandır Lahdi'nin her tondosu içindeki bir çift, birer karı-kocayı temsil etmektedir ve dolayısıyla bu çiftlerin lahdi kullandığı söylenebilir ${ }^{9}$. Tabula ansata üzerindeki yazıta bağlı olarak tondolar içindeki çiftlerin isimlerine ilişkin öneri getirilecektir. Ayrıca Phaselis teritoryumunda bulunmasına rağmen Hisarçandır Lahdi üzerindeki gibi büstler, Phaselis kent nekropolislerinde yer alan lahitler üzerinde bulunmamaktadır ${ }^{10}$. Bu farkın sebebi Phaselis teritoryumu içerisinde olsun veya olmasın Hisarçandır'ın da içinde bulunduğu dağık yakın civarın, Lykia, Pisidia ve Pamphylia kültür bölgelerinin etki alanında kalması ve bu kültürel zenginliğin etkisiyle de kendine özgü bir lahit anlayışı oluşturmasıyla açıklanabilir. Hisarçandır Lahdi ön yüz sağ alt tarafta Eros'lu av sahnesi görülür (Fig. 12). Arkasında köpek bulunan Eros elinde mırağı ile kaplana hamle yapmaktadır. Vahşi hayvanların avlanması aristokratik bir anlam içerir ${ }^{11}$. Yırtıcı hayvanları avlama veya öldürme sahnelerinin kökeni doğu dünyası olup, erken örneği MÖ IV. binyıl sonlarına inmektedir ${ }^{12}$. Anadolu'da Hatti veya Hatti-Hitit Beylikler Dönemi'nde ${ }^{13}$ yaklaşık MÖ II. binyıl ilk çeyreği veya içerisine tarihlenen Asur Ticaret Kolonileri Çağı'nda ${ }^{14}$ aslan avı sahneleri özellikle mühürler üzerinde bulunur ${ }^{15}$. Aslan avı, Hitit Dönemi'nde Alacahöyük orthosthatı üzerinde görülür ${ }^{16}$. Geleneğin devamı olarak sahne, Geç Hitit Dönemi orthosthatlarında betimlenir ${ }^{17}$. Geç/Yeni Hitit Dönemi'nde bu tip mücadele sahneleri

8 Koch 2001, 68 vd.; Üzerinde büst bulunan Roma Dönemi lahit örnekleri için bk. Koch - Sichterman 1982, 117 vd.; Kranz 1984, 191 vd.; Kranz 1999, 138 vd.; Ayrıca kayaya oyulu lahit tekneleri üzerinde de büstler olabilmektedir, bk. Durukan 2007, 147-149, res. 2; Phaselis teritoryumu ve yakın çevresinde kabartma büstlü lahit örnekleri için bk. Özdilek - Çevik 2009, 285 vd.; Tüner Önen et al. 2017, 346 vd.; Ayrıca Antalya Müzesi'nce 2013 yılında yapılan kazıyla Hurma Mahallesi'nde ortaya çıkarılan ve 2013/181 envanter numarası alan lahit üzerinde benzer büstler bulunmakta olup, bu lahit Ahmet Çelik tarafından yayına hazırlanmaktadır.

9 Termessos'ta MS 150-200 arasına tarihlendirilen bir lahdin uzun yüzünün sağ çelengi içerisinde erkek, sol çelengi içerisinde başı örtülü kadın büstü bulunan ve yazıtından, Ailia Kapetoleina Kille adlı bir kadın tarafından kendisi ve kocası Tiberius Claudius Agrippeinus için lahdin yaptırıldığı anlaşılmaktadır, bk. Çelgin 1990, 260-268.

10 Phaselis nekropolis'lerinde bulunan lahitler genelde sade ve bezemesizdir, ayrıca bk. Gürel 2016, 281 vd.

11 Strootman 2014, 201.

12 Kaplan avlama veya öldürme sahnesinin benzeri olan aslan öldürme sahnesinin erken örneği Güney Irak Uruk'ta, MÖ IV. binyıl sonlarına tarihlenen bazalt bir stel üzerinde aslan öldüren kral sahnesiyle görülür. Daha sonra bu ikonografi Asur sanatında devam eder, bk. Özüdoğru 2013, 72; Buna ek olarak Eski Mısır Thebes Krallar Vadisi'nde, 20. Hanedanlığın Üçüncü Orta Periyodu içerisinde MÖ 1100-700 arasına tarihlendirilen kireçtaşı parça üzerinde firavun mızrağıyla aslan avlarken arkasında köpeği görülmektedir. Arnold 1995, 16.12.

13 Yerli Anadolu kökenli Hattilerin etkin olduğu dönem MÖ 2500-2000/1700 yıllarına tarihlendirilmektedir. Hint-Avrupa kökenli bir kavim olan Hititlerin zamanla nüfusları artmış ve MÖ XVII. yüzyıl ortalarında Anadolu'nun başat krallığı olarak tarih sahnesinde rol oynamaya başlamışlardır. Daha detaylı bilgi için ayrıca bk. Akurgal 1998, 15 vd.

14 Asur Koloni Çağı yaklaşık 200 yıl sürmekle beraber MÖ 1970-1750 arasına tarihlendirilmektedir ve bu dönemde Asurlu tüccarlar vasıtasıyla Anadolu yazıyla tanışmıştır. Öz 2005, 2-4. Bu dönem Asur Sömürgeler Dönemi olarak ta adlandırılmaktadır ve MÖ 1900-1800 arasına tarihlenmektedir, bk. Akurgal 1998, 40-41.

15 Küsmez 2009, 9 vd.

16 MÖ XV-XIV. yüzyıla tarihlendirilmektedir. Akurgal 1995, şek. 58, res. 51-b.

17 Akurgal 1995, Malatya Aslantepe (MÖ 850-750) res. 112-a, Sakçegözü (MÖ 750-700) res. 118-a, Tell Halaf (MÖ 725-700) şek. 126. 
Frig üzerinden Batı Anadolu'ya ve dolayısıyla Ionia'ya da aktarıımıştır ${ }^{18}$. Lykia'da MÖ VI. yüzyıl ortalarına tarihlendirilen Ksanthos Aslanlı Dikme üzerindeki aslan öldürme sahnesinin Geç Hitit etkisiyle yapılmış olabileceği değerlendirilmektedir ${ }^{19}$. Roma Dönemi'nde lahitlerin seri üretiminden önce, MÖ IV. yüzyıl sonlarına tarihlendirilen İskender Lahdi'nin bir kısa yüzünde panter avı sahnesi görülmektedir ${ }^{20}$. Bu bağlamda geçmiş ikonografinin devamcısı olarak Roma Imparatorluk Dönemi içerisinde aslan ya da kaplan avı yapan Eros sahneli lahitler genellikle MS II-III. yüzyıl tarihlendirilirr ${ }^{21}$. Ayrıca, bir lahit üzerinde aslan veya kaplan avlama, ölüme galip gelme manası taşır ${ }^{22}$.

Lahit ön yüz sol alt tarafta ise aslan ile boğa mücadele sahnesi görülür

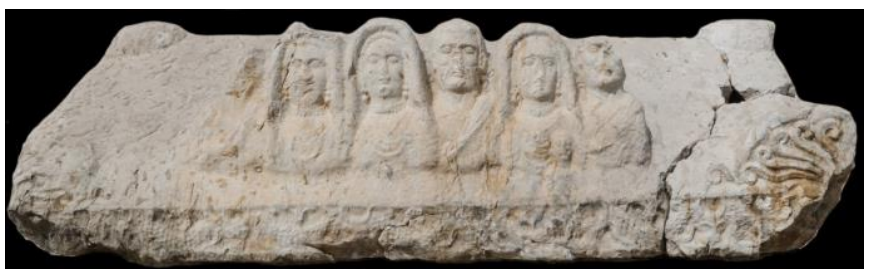

Fig. 9 Lahit Kapağı ön yüz fotoğrafı

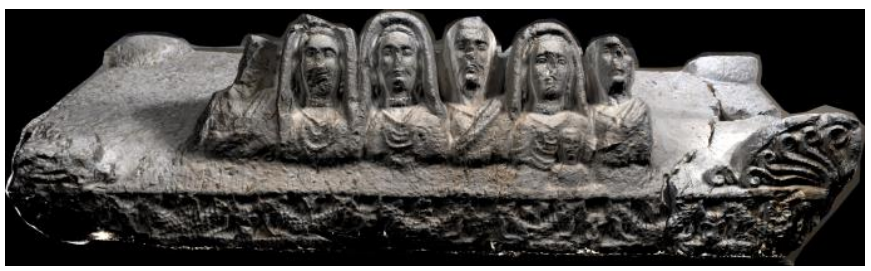

Fig. 10 Lahit Kapağı ön yüz (RTI: default )

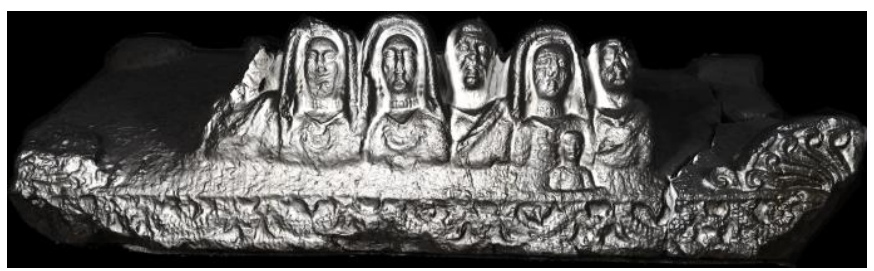

Fig. 11 Lahit teknesi ön yüz (RTI: specular enhancement) ve aslan sol pençesi ile boğayı parçalamaktadır (Fig. 13). Vahşi hayvan av sahnelerinde olduğu gibi aslan-boğa mücadelesi de çok eski bir geçmişe sahiptir ve yine doğu sanatı yaratısıdır. Bu tip mücadelenin erken örneği MÖ IV. binyıl sonlarına tarihlenen bir Sümer vazosu üzerinde görülür ${ }^{23}$. Hitit Büyük Krallık ${ }^{24}$ veya İmparatorluk Dönemi'ne ait tunç bir kap üzerinde aslan-boğa mücadelesi bulunur ${ }^{25}$ ve bu konu Asur sanatında da işlenmiştir ${ }^{26}$. Daha sonra Lidya sikkelerinde örneğin; MÖ 560-546 arasında Kroisos Dönemi'nde aslan-boğa mücadelesi bulunur ve bu kompozisyon Pers sikkelerinde de devam etmiştir ${ }^{27}$. Lykia'da genel olarak MÖ IV. yüzyıla tarihlendirilen Myra Doğu Nekropolis'inde tapınak cepheli bir kaya mezarının alınlığında aslan-boğa mücadelesi sahnelenmiştir ${ }^{28}$. Konuya ilişkin Roma öncesi lahitler için bir örnek verilecek olursa, MÖ 330-300 arasına tarihlendirilen bir Etrüks lahdi üzerinde iki aslan bir boğayı parçalamaktadır ${ }^{29}$. Yine gelenek devam etmiş ve Roma Imparatorluk Dönemi'nde, 150/160-250 yılları arasında,

18 Işık 2003, 22, dn. 11.

19 Özüdoğru 2013, 69 vd.

20 Hamdi Bey - Reinach 1892, 272 vd. PI. 28.; Heckel - Tritle 2009, 34, fig. 2.3-2.4.

21 Koch 2001, 122; Örneğin Kelbessos'ta Roma Dönemi'ne ait nekropolis'te ön yüzünün üç tarafı üzüm asması ile bezeli lahdin sol alt kenarında bir figür elinde mızrakla aslan veya kaplan avlamaktadır; ayrıca bk. Çevik 2008, 208-209, res. 22. Phaselis teritoryumu ve yakın çevresinde tespit edilen yerel üretim bazı lahitler üzerinde benzer av sahneleri görülmektedir; bk. Özdilek - Çevik 2009, 286. Koch 2001, 79.

23 Yıldırım 2003, 3

24 Hitit Büyük Krallık Devri MÖ 1460-1190 arasına tarihlenmektedir, bk. Akurgal 1995, 37.

25 Hitit Imparatorluk Çağı'na tarihlenen ve günümüzde Kastamonu Müzesi'nde bulunan Taprammi Kabı üzerinde aslan-boğa mücadelesi gösterilmiştir. Otlu 2014, 60-62, lev. 38.1, 1A-39.1B

26 MÖ VIII. yüzyıla ait Asur bronz diski üzerinde aslan-boğa mücadelesi görülür, bk Yıldırım 2003, 3.

27 Bodzek 2014, 60, res. 3-4;

28 Texier 1865, 53, pl. 46; Çevik 2015, 366-367.

29 Bk. Cohen 2010, 101-102, res. 43. 
karşısındaki boğayı parçalayan aslan sahneleri nadir olmakla beraber lahitler üzerinde veya kapaklarında gösterilmiştir ${ }^{30}$. Boğayı parçalayan aslan, düşmana galip gelmeyi veya muzaffer tarafı simgelerken boğa ise mağlubiyeti ya da yenilen tarafı temsil eder ${ }^{31}$. Bu bağlamda simetrik yerleştirilen hem kaplan avı sahnesi hem de aslan-boğa mücadelesi ölümü yenmenin yanında düşmana galip gelmeyi niteleyen bir zafer sahnesi olmalıdır.

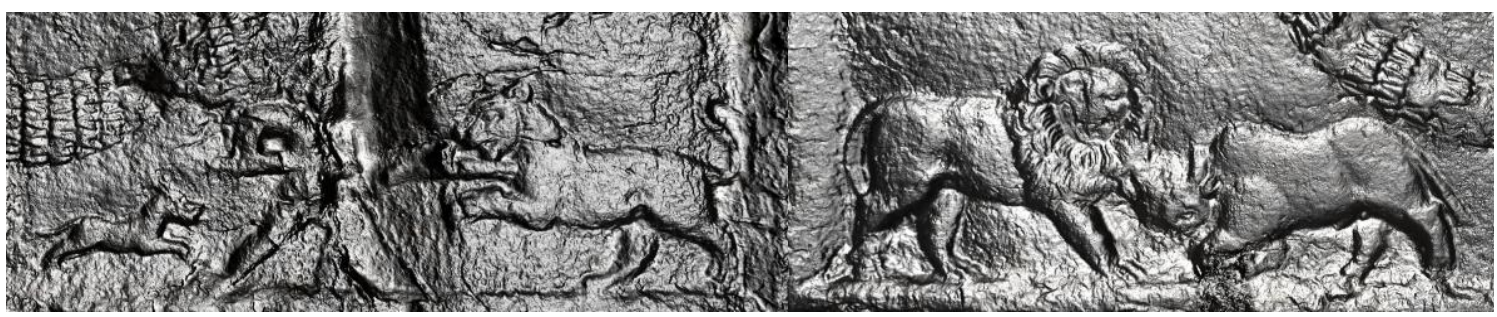

Fig. 12 Av sahnesi

(RTI: specular enhancement)
Fig. 13 Aslan-boğa mücadelesi

(RTI: specular enhancement)

Ön yüz en alt tarafta hayvanlar frizi bulunur (Fig. 8). Merkezde karşılıklı duran iki aslanın ${ }^{32}$ arasında krater görülür (Fig. 14). Buna benzer kompozisyon Roma Dönemi Pisidia lahdinden tanı$n ı r^{33}$. Ancak, Hisarçandır Lahdi'nde farklı olarak kraterin içerisinde bir bitki bulunmaktadır. Bu bitki, hayat ağacını temsil etmelidir. Hayat ağacının sanata erken yansıması iki hayvan (teke) arasındaki bitki kompozisyonu ile hayat ve ölüm arasındaki döngünün bir işareti olarak MÖ III. binyılda Sümerler ile görülür ${ }^{34}$. Bunun dışında Hurri, Asur, Babil, Hitit, Mitanni, Frig, Urartu ve Geç Hitit sanatında hayat ağacı motifi kullanılmıştır. Hayat ağacı şansı, bereketi ve doğurganlığı simgelemenin yanında öldükten sonra dirilişi temsil etmektedir ${ }^{35}$. Seri üretim sonrası benzer kompozisyon Roma lahitlerinde de görülmektedir ${ }^{36}$. Dolayısıyla Hisarçandır Lahdi üzerinde iki aslan arasındaki hayat ağacı sahnesinin ölümden sonraki dirilişi sembolize ettiği düşünülebilir.

Çok yıpranıp belirsizleştiğinden tam olarak seçilememekle beraber, frizin sağına doğru iki kaplan aralarındaki bir boğayı veya bir av hayvanını(?) parçalamaktadır. En dışta ise geriye dönüp bakan ve sol pençesiyle volütlü kratere dokunan noktacık benekli bir panter görülür (Fig. 15). Frizin soluna doğru bir kaplan, önündeki boğanın veya bir başka av hayvanın(?) sol arka bacağının ısııırken, bu kaplanın önündeki

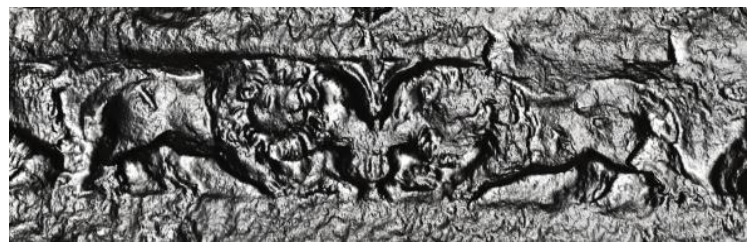

Fig. 14 Aslan-boğa mücadelesi (RTI: specular enhancement)

30 Koch 2001, 153; Antakya'dan MS III. yüzyıl ortalarına tarihlendirilen bir lahitte, simetrik yerleştirilen 2 aslan 2 boğayı parçalamaktadır, Bk. Koch - Sichterman 1982, 445, res. 475; Ayrıca Roma Dönemi lahit kapağında da aslan-boğa mücadele sahnesi gösterilmektedir; ayrıca bk. Kızgut et al. 2009, 155, res. 30; bir başka örnek için bk. Tüner Önen et al. 2017, 352, Fig. 12.

31 Yıldırım 2003, 2 vd

32 Mezarlarda kullanılan aslan kabartmalarının, beyin gücü ve siyasi erki göstermenin yanı sıra mezar koruyucusu vasıflarının bulunduğu belirtilmektedir. Ayrıca aslan Ana Tanrı́nın kutsal hayvanı olarak Kybele ile ilişkilendirilmiştir, bk. Dökü 2008, 87-91.

33 Termessos'ta Roma Dönemi'ne ait S5 Nolu Mezar'daki Pisidia Lahdi üzerinde aslan ve kaplan arasında amphora bulunmaktadır. Burada amphoranın içerisinden çıkan bir bitki bulunmamaktadır; ayrıca bk. Lanckoroński 1892, 63, 109-112.

34 Belli 1980, 238.

35 Çevik 1999, 335 vd.; Ağacın kış mevsiminde ölüp ilkbaharda yeşermesi insanın ilgisini artırmış, bu yönüyle ağaç, ölüm ve yaşamı sembolize etmiştir, bk. Köroğlu 1996, 35

36 Örnek için bk. Koch - Sichterman 1982, 236-238, res. 278. 
bir başka kaplan, volutlü krater ile arasındaki pantere hamle yapmaktadır (Fig. 16).

Hayvanlar sırasının lahitlerde dekoratif amaçlı mı? yoksa mezar geleneğiyle bağlantılı inanç siteminin bir parçası olarak mı? tercih edildiğini belirlemek zordur. Vazo sanatından da tanınan sıralı hayvanlar frizinin, alanı dolduran bir süsleme unsuru olabileceği gibi özellikle içlerinde barındırdıkları aslan-kaplan gibi yırtıcılarla, kent kapılarındaki vasıflarına binaen mezar koruyucusu olarak bir anlam taşıdığını da düşünmek gerekir.

Hisarçandır Lahdi'nin her iki yanın-

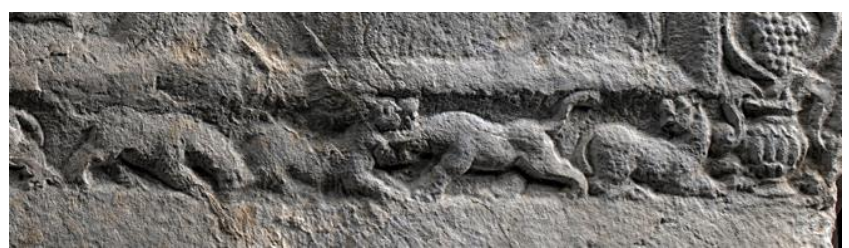

Fig. 15 Hayvanlar frizi sağ taraf (RTI: image unsharp masking)

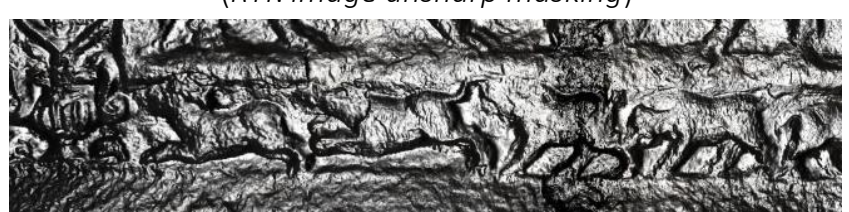

Fig. 16 Hayvanlar frizi sol taraf

(RTI: specular enhancement) merkezinde volutlü krater içerisinde birleşmektedir (Fig. 8).

Krater içerisinden çıkan asma dalı bezemesi lahitlerde ${ }^{38}$ bulunmakla beraber asma ya da üzüm Dionysos dünyasıyla bağlantılı olabilir ${ }^{39}$. Mezar ikonografisinde kullanılan asma-üzüm yine bolluk ve bereketi simgeler ${ }^{40}$. Ancak, Hisarçandır Lahdi üzerinde hayvanlar frizinin köşelerindeki birer panterin pençeleriyle kratere dokunmuş olması ve içerisinden asmanın çıkması, merkezdeki hayat ağacı kompozisyonunu anımsatmaktadır. Dolayısıyla hayat ağacı gibi asma-üzüm de öldükten sonra dirilişi simgeliyor olabilir ve bu nedenle lahitlerde tercih edildiği düşünülebilir ${ }^{41}$. Ayrıca asma-üzüm motifinin bölgedeki dönemin kırsal yaşamına da işaret ettiği söylenebilir ${ }^{42}$. Nitekim Beydağları civarında, Roma Imparatorluk Dönemi'nin MS III-IV. yüzyıllarına tarihlenen kırsal yaşam konulu yerel üretim lahitler tespit edilmiş olup, bunlar dönemin bölgedeki tarımsal faaliyetlerine tanıklık etmesi ve kırsal yerleşmelere ilişkin kayıtları göstermesi bağlamında

Termessos'ta Roma Dönemi'ne ait S5 Nolu Mezar'daki Pisidia Lahdi ön yüzünün her iki köşesi asma-üzüm motifi ile bezenmiştir, bk. Lanckoroński 1892, 111, res. 78. Asma-üzüm bezemeli bir başka örnek olarak Kartınpınarı'ndaki MS III. yüzyıl tarihli lahit gösterilebilir, bk. Akalın 2008, 27 vd. Benzer örnekler için ayıca bk. Özdilek - Çevik 2009, 285 vd.; Tüner Önen et al. 2017, 349 vd.

381940 yılında Side'den getirilip günümüzde 345 envanter numarası ile Antalya Müzesi teşhirinde sergilenen lahit, ana grup lahitlere benzemediğinden Geç Hellenistik veya Erken Roma Imparatorluk Dönemi başlarına tarihlenmektedir. Ancak bu tarihleme kesinlik kazanamadığından sandık veya kabartma frizli lahitlerin öncüsü olup olmadığı da kesinleşmemiştir, bk. Koch - Sichterman 1982, 482, 540, res. 531; Karaüzüm 2005, 10.

39 Perge'de bulunup MS III. yüzyılın ikinci yarısına tarihlendirilen ve üzerinde asma bulunan lahit Dionysos dünyasıyla bağlantılıdır; konuya ilişkin olarak ayrıca bk. Koch - Sichterman 1982, 421 res. 450; Turak 2012, $223 \mathrm{vd}$.

40

Abay 2016, 333.

41 Nitekim asma ölünün öbür dünyadaki ruhunun ölümsüzlüğünü temsil etmektedir. Tüner Önen et al. 2017, 362; Ayrıca Olympos'ta MS II. yüzyıl ortaları ile son dörtlüğü arasına veya MS II. yüzyıl sonu-III. yüzyıl başına tarihlendirilen Antimakhos Lahdi'nin plasterlerinin alt bölümünde bir kap (kantharos) içerisinden çıkmakta olan sarmaşık dalları hayat ağacı olarak nitelendirilmektedir, bk. Özer 2013 (a), 486, 496, res. 5-6.

42 Konya Koyunoğlu Müzesi'ndeki bir stel üzerinde asma-üzüm betimi bölgede yaşayan insanların bağcılıkla uğraşıı̆ıını düşündürmektedir. Abay 2016, 333; Benzer ikonografiye sahip bir başka stel örneği için bk. Özsait et al. 2009, 202, res. 11. 
önemlidir ${ }^{43}$. Bu lahdin bulunduğu yerin yakınında çiftlik evi ve işlik kalıntıları düşünüldüğünde, asma-üzüm bezemesinin mezar geleneğiyle bağlantılı taşıdığı diğer anlamlarının yanında mezar sahibinin yaşadığı kırsalı belki tarımla uğraşan kimliğiyle birarada gösteriyor olmalıdır ${ }^{44}$.

Hisarçandır Lahdi'nin sağ ve sol kısa yüz merkezinde 8 yapraklı açmış rozet bulunan birer kalkan bulunmaktadır. Bunların altına sağda kabzası içinde bir kılıç yerleştirilmişken solda mızrak bulunur (Fig. 5-6).

Erken Hellenistik Dönem tarihli Termessos Alketas Mezar ${ }^{45}$, mezar geleneği bağlamında kalkan betiminin iyi bir örneğidir ve burada kalkan, mezar sahibinin savaş̧̧ı kimliğinin yanında heroize edildiğini veya tanrılaştığını gösterir ${ }^{46}$. Roma Dönemi'ne ait ${ }^{47}$ Trebenna Trokondas Mezarı, özel konumunun yanı sıra kült amaçlı kaya döşemleriyle bir Ölü Tapınağı görünümü sergilemektedir ve kapısının üzerindeki kalkan ile Alketas Mezarı'ndaki düşüncenin yansımış olduğunun belgesidir $^{48}$

Hellenistik Dönem'den itibaren Pisidia osthotekleri üzerinde kalkan ve kılıç gibi silah betimleri görülürken Roma İmparatorluk Dönemi Pisidia lahitleri üzerinde de belirli bir kalıba uyarlanarak benzer silahlarla süsleme geleneği sürmüştür ${ }^{49}$. Dolayısıyla Hisarçandır Lahdi, özellikle üzerindeki silah betimlemeleriyle Pisidia geleneğinin devamı niteliğindedir.

Hisarçandır Marcus Aurelius Kamoas Lahdi kapağının merkezi ve köşe akroterlerinin ana hatları belirlenmiş olup, sadece ön yüz tarafındaki akroterlerde palmet motifi işlenmiştir (Fig. 9-11). Anadolu lahit kapaklarının köşe akroterlerinde palmet ve/veya yapraklı düzenlemeler yaygındır ve bunun yanında figürler de olabilmektedir ${ }^{50}$.

Kapağın her iki alınlığında olasılıkla antik soygunla bir bölümü tahrip olmuş birer Medusa ${ }^{51}$

43 Beydağları Yüzey Araştırmaları ekibince 1997-2006 yılları arasında Lykia, Pamphylia ve Pisidia sınır bölgelerinde kalan Trebenna, Kelbessos, Typallia, Hurma, Kartınpınar ve Gedeller gibi yerlerde kırsal yaşam konulu çok sayıda lahit tespit edilmiştir. Bu lahitlerin çoğu Pisidia motifleri taşımakla beraber bunların bir bölümü tabula ansata'lı-Kalkanlı ve tabula ansata'lı-Figürlü olarak iki başlık altında değerlendirilmiştir. Özdilek - Çevik 2009, 284-287; Söz konusu arazinin bir bölümü Phaselis teritoryumu içerisinde bulunurken bir kısmı dışındadır. Gürel 2016, 280, fig. 1; Bu bağlamda Phaselis teritoryumu içerisinde yer alan Yaylakuzdere'de tespit edilip genel tipoloji açısından Hisarçandır Lahdi'ne oldukça benzeyen lahitler, MS II-III. yüzyıllara tarihlendirilmişlerdir, bk. Tüner Önen et al. 2017, 343 vd. Hisarçandır Lahdi'nin yaklaşık 400 m kuzeydoğusunda tepe üzerine konumlanan bir çiftlik yerleşimine ait yapı grubunun bulunduğu, seramik parçaları ile işliğe (rapor eki fotoğraflardan zeytin işliği dışında üzüm işliği de bulunduğu söylenebilir) rastlandığı Antalya Müzesi'nin 21.11.2008 tarihli uzman raporundan anlaşılmaktadır.

45 Lanckoroński 1892, 68; ayrıca bk. Abbasoğlu 1987, 214; Çelgin 1994, 158-160.

46 Işık 2015, 204.

47 Bu mezarın en geç MS I. yüzyıla tarihlenmesi gereken, kurucu ailenin bilinebilen tek kaya mezarı olması beklenir. Çevik et al. 2005, 67-68.

Işık 2015, 204.

49 Lanckoroński 1892, 106 vd.; Koch - Sichterman 1982, 544-550; Çelgin 1990, 88 vd.; Koch 2001, 259-260; 2010, 31-32; Pisidia lahitlerinde kullanılan kalkan, savaşçılığı göstermenin yanında, düşmana karşı hazırlık, güç, iktidar, hâkimiyet ve kötülüklerden koruyup caydırma gibi anlamlar içermektedir, bk. Özdilek 2006, 3436. Genellikle üzerinde tabula ansata ve iki kalkan bulunan Roma Dönemi Pisidia Lahitleri, yazıtları ve kabartma stilleriyle MS III. yüzyıla tarihlenebilirler, bk. Özdilek - Çevik 2009, 284. Konuyla ilintili Phaselis teritoryumu ve yakın çevresinde Pisidia geleneğini yansıtan kalkan betimli lahit örnekleri bk. Tüner Önen et al. 2017, 346 vd. Ayrıca Antalya Müzesi ön bahçesinde bulunan 2013/181 envanter numaralı Hurma Lahdi'nin kısa yüzlerinde de benzer kalkan örnekleri bulunmaktadır.

50 Koch 2001, 205

51 Mitolojide saçları yılanlarla örülü, tunç elli, altın kanatlı ve bakışlarıyla insanı taşa çeviren Gorgo Medusa’yı 
başı yer alır (Fig. 5-6). Medusa korkutucu ve koruyucu özellikte olduğundan mezarlarda tercih edilmiş $^{52}$ ve Roma'dan çok önceki bir süreçte mezar ikonografisinde yerini almıştır ${ }^{53}$. Medusa başının ana/merkezi figüratif unsur olarak kullanıldığı lahit teknesi örnekleri ${ }^{54}$ bilinmekle birlikte Roma Dönemi'nde özellikle girlandlı lahitlerde çelenk boşluklarında yer almışıı ${ }^{55}$. Ayrıca, Hisarçandır Lahdi'ne benzer biçimde Medusa başı üçgen alınlıklı lahit kapakları üzerinde de yaygın kullanılmışıı ${ }^{56}$.

Kapağın lahit teknesine oturduğu ön taraftaki kuşakta 7 adet girland ile bunların taşıyıcısı 8 adet boğa başı bulunmaktadır (Fig. 9-11). Girland boşluklarında zorlukla seçilebilen rozet veya başkaca bitkisel bezeme kullanıldığı anlaşıımaktadır.

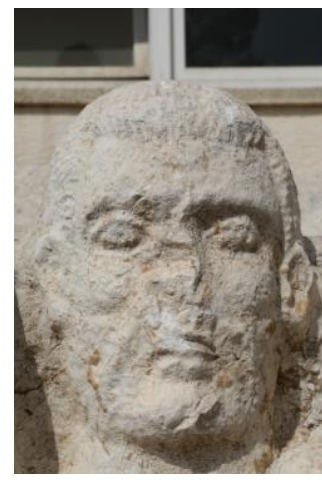

Fig. 17 Ortadaki erkek başı

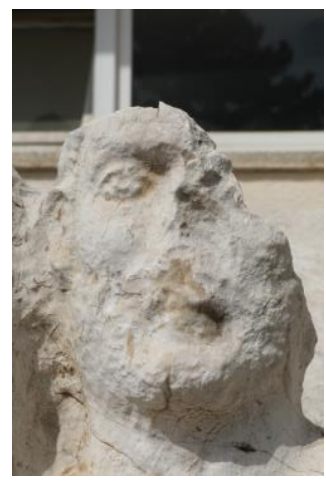

Fig. 18 Sağdaki erkek başı

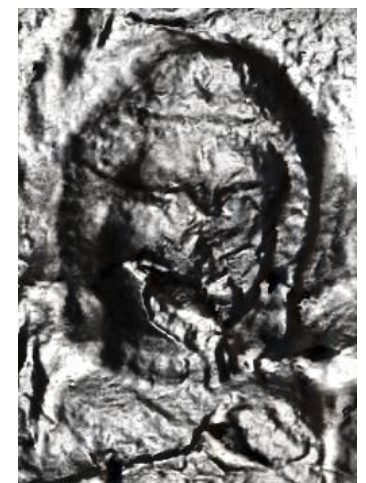

Fig. 19 Sağ tondo kadın büstü (RTI)

Kapak üzerinde yüksek kabartma 3 erkek ve 3 kadın büstü bulunmaktadır (Fig. 9-11). Erkeklerden ortadaki sağlamken diğer ikisinin bir bölümü tahrip olmuştur. Kadın büstleri büyük oranda sağlamdır. Ayrıca kadın büstlerinden birinin önünde zorlukla seçilebilen alçak kabartma çocuk büstü bulunur. Roma Imparatorluk Dönemi lahit kapaklarında nadir olmakla birlikte yüksek kabartma biçiminde büstler bilinmektedir ${ }^{57}$. Bu açıdan Hisarçandır Marcus Aurelius Kamoas Lahdi, kapağında taşıdığı nadir görülen yüksek kabartma büstler ile özellikli bir konumdadır. Bunun dışında Hisarçandır Lahdi kapağındaki çocuk kabartmasında olduğu gibi Roma Dönemi'nde daha alçak kabartma büstlere sahip lahit kapağı örnekleri de görülür ${ }^{58}$.

Perseus öldürmüştür. Erhat 1972, 149; Fuchs 1979, 397-398, 407; Grimal 1997, 217-219; Carpenter 2002, 106 vd.; Cömert 2014, 79 vd.

52 Medusa başlarının lahitlerde kullanıımasının amacı mezarın korunması ve bekçiliktir, bk. Şimşek 1998, 4.

53 Medusa'nın erken kullanımına örnek, Limyra kökenli olup, MÖ 380-360 yılına tarihlendirilen semerdam biçimli lahit kapağının dar yüzünün üst kirişi üzerinde bir Medusa başı gösterilebilir, bk. İdil 1981, 86-87, lev. 31.1-2. Buna ek olarak MÖ 370-360 yıllarına tarihlenen Perikle Heroonu üzerinde Perseus-Medusa mitolojisi anlatılmıştı;; konuya ilişkin daha detaylı bilgi için ayrıca bk. Borchhardt 1976, 83 vd.; Şahan 2009, 47-48.

54 Koch - Sichterman 1982, 352, 500, res. 388, 483; Waelkens 1982, 57, lev. 18,1; Huskinson 2015, 167; Ayrica 1947 yılında Perge'de bulunup Antalya Müzesi'nde sergilenen 380 envanter numaralı Madalyonlu Medusa Lahdi iyi bir örnektir.

55 Girland üstü boşluklarda Medusa başı kullanılan lahit örnekleri için bk. McCann 1978, 31-33; Işık 1982, 35 vd.; Waelkens 1982, 20 vd.; Herdejürgen 1996, 83 vd.

56 İdil 1981, 54 vd., lev. 7.1, 36.1-2, 79.2; Waelkens 1982, 17, lev. 1,1; Cambi 2010, 63 vd.; Ayrıca Antalya Müzesi'nde 2013/181 envanter numaralı Hurma Lahdi kapağı dar yüzlerinde de Medusa başı görülmektedir.

57 Örneğin Roma'dan MS I. yüzyılın son çeyreğine tarihlendirilen bir lahdin kapağında eşinin yanında bir kadına ait yüksek kabartma bulunmaktadı; konuya ilişkin olarak bk. Koch - Sichterman 1982, 60, res. 61. Ayrıca, Hierapolis'te bir lahdin kapağının uzun yüzünün ortasında bir çiftin büstü bulunmaktadır. Neredeyse tam plastik nitelikteki büstlerin sevilerek yapılan bir süsleme biçimi olduğu değerlendirilmektedir, bk. Koch 2001, 253.

58 Örneğin Köln ve Trier'den MS III. yüzyıl tarihli lahitlerin kapaklarında alçak kabartma büstler bulunmaktadır; 
Hisarçandır Lahdi kapağı üzerindeki ortadaki ve sağdaki erkeğin saçının kısa tıraşlı olduğu ve ayrıca her ikisinde de zorlukla seçilebilmekle birlikte yüzlerinde kısa sakal bulunduğu anlaşılmaktadır (Fig. 17-18). Saç ve sakal çentikler halindedir. Roma Imparatorluk Dönemi erkek portrelerinde bu tip saç yapısı MS III. yüzyıl ilk çeyreği sonları ${ }^{59}$ gibi görülmeye başlar ve 250 civarında iyice yaygınlaşır ${ }^{60}$. Öte yandan her iki başın kaş, göz, ağız, çene ve yüzün genel yapısı da döneminin karakteristik özelliklerini yansıtmaktadır.

Örtü altında olması nedeniyle başlarının üst bölümü görülemeyen Hisarçandır Lahdi kapağı üzerindeki kadınların saçları yerel sanatın doğal bir sonucu olarak şematik çizgilerle iki yana ayrılmıştır (Fig. 9-11). Ancak sağ kalkan tondosu içerisindeki kadının başının tepe bölümünde şapkayı andıran saç öbeği zorlukla da olsa algılanabilmektedir (Fig. 19). Hem bu saç öbeği ve hem de erkek saç modası ile birliktelik göstermesi gerektiğinden dönemin modasına uygun olarak sağ tondodaki kadın saçının ortadan ayrıldıktan sonra yanlara ayrıldığı, kulakları hafif açık bıraktıktan sonra geriye tarandığı ve arkaya alınıp önce enseye inen saçların yukarı döndürüldükten sonra başın tepe bölümünde içe doğru toplanarak tutturulduğu söylenebilir ve bu saç yapısı "scheitelzopf" olarak adlandırımaktadır ${ }^{61}$. Bu tip kadın saç modeli MS III. yüzyılın ikinci çeyreğinden itibaren $^{62}$ görülürken bu yüzyılın ortaları gibi modası yerleşir ${ }^{63}$.

Hisarçandır Marcus Aurelius Kamoas Lahdi kapağı üzerindeki kadınların büyük küpe ve gerdanlık taktığı görülmektedir. Bu tip gösterimin refah ve zenginliğin bir işareti olduğu değerlendirilmekle birlikte buradaki takılar üzerinden bir tarihlemeye gitmek mümkün değildir. Ancak Roma Dönemi'nde son derece çeşitli, renkli ve üst düzey işçilikli takı örnekleri verilmiştir ${ }^{64}$.

Hisarçandır Lahdi kapağındaki yüksek kabartma büstlere benzer gösterimin yakın örneği Burdur Müzesi'nde bulunmaktadır ve MS III-IV. yüzyıla tarihlendirilen yerel işçilikli lahit kapağı üzerinde, oldukça sade giysili karı-kocaya ait yüksek kabartma bir büst bulunmaktadır ${ }^{65}$. Ayrıca Elmalı Müzesi'nde bulunan bir lahit kapağı üzerinde bu kadar yüksek olmasa da bir kadın ve bir erkeğe ait yerel işçilikli büst görülür ${ }^{66}$.

Hisarçandır Lahdi kapağı üzerindeki yüksek kabartma figürler, onlar kadar ince ve detay işçilikli olmamalarına rağmen, Roma Dönemi içerisinde Palmyra örneklerini anımsatmaktadır. Çünkü Palmyra'da da mezar geleneğiyle bağlantılı büstlerde son derece zengin mücevherlerle kadınların tezyin edildiği görülmektedir ${ }^{67}$. Palmyra lahitleri yerel kireçtaşından mamuldür, üzerlerinde büstler de olabilmektedir ve MS II. yüzyıl sonu ile III. yüzyıl ilk yarısına tarihlenmektedirler ${ }^{68}$.

bk. Koch - Sichterman 1982, 301-302, res. 323, 326.

59 Benzer saç yapılarındaki örnekler için ayrıca bk. Wood 1987, $115 \mathrm{vd}$.

60 Örneğin olasılıkla imparator Traianus Decianus'a ait MS 249-251 yıllarına tarihlendirilen bir portrede benzer şekilde saç ve sakal yapısı görülür, bk. Frel - Morgan 1987, 105; Dönemin imparatorlarından Gallienus'a ait 253-268 ve 254-260 yıllarına tarihlendirilen 2 portrede benzer saç ve sakal yapısı bulunmaktadır; bk. Turak 2005, 55 res. 114.

61 Turak 2005, 56-57.

62 Frel - Morgan 1987, 107 res. 88.

63 Örnekler için bk. Sande 1987, 137-141; Iş̧an 2002, 256-262 res. 1-10.

64 Roma takı örnekleri için detaylıca bk. Marshall 1911, 272 vd.; Oliver 1966, 282 vd.; Higgins 1980, 9 vd.; Ogden 1991, $30 \mathrm{vd}$.

65 Burdur Gölü'nün batııında Aşağı Müslimler civarından geldiği belirtilen ve Burdur Müzesi'nde sergilenen lahit kapağı K.80.36.01 envanter numaralıdır.

66 Elmalı ilıçesi, Geçit Köyü, Balıklar Dağı Mevkii'nden getirilip Elmalı Müzesi bahçesinde sergilenen ve MS II-III. yüzyıla tarihlenen lahit kapağı 2011/9 envanter numaralıdır.

67 MS II-III. yüzyIla tarihlendirilen örnekler için bk. Kenaan-Kedar 2012, 111 vd.

68 Koch 2001, 274-275. 
Hisarçandır Lahdi'nin bulunduğu yer ile günümüzde Suriye topraklarındaki Palmyra'nın uzak mesafesi düşünüldüğünde bir etkileşimden söz etmek pek mümkün görünmemekle beraber en azından Doğu Dağlık Lykia sınırında da bir lahit üzerinde kadınların ziynet eşyalarıyla süslü gösterilmesine yönelik anlayışı yansıtan bir örneğin bulunduğu söylenebilir.

\section{Tabula Ansata ve Yazit}

Tabula ansata'lar, çoğu zaman üç köşeli veya sarkaç biçimli kulpludur ve bunlar genelde yazıt amaçlıdır; "kulplu anı tabelası" anlamına gelir" 69 . Lahitteki tabula ansata üzerindeki yazıt ve çözümü şu şekildedir ${ }^{70}$ (Fig. 20).

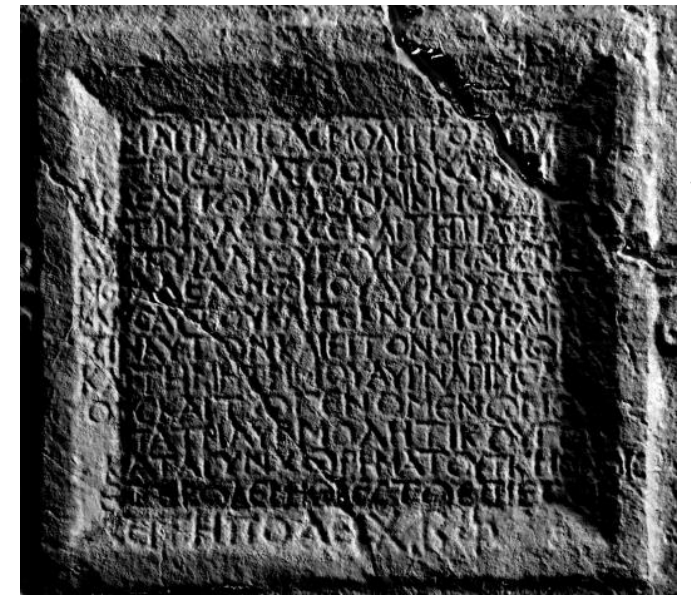

Fig. 20. Tabula ansata ve yazıt (RTI)

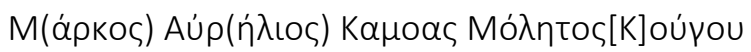

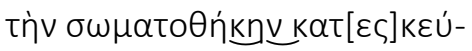

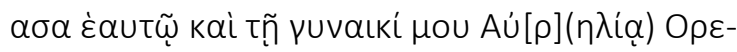

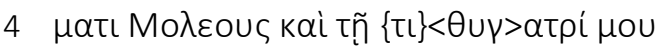

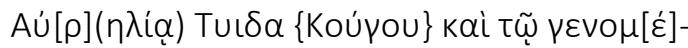

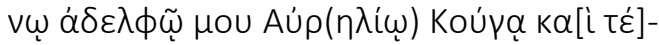

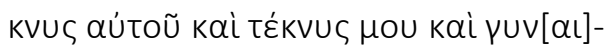

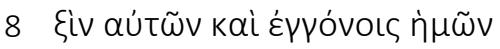

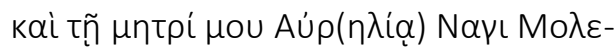

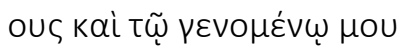

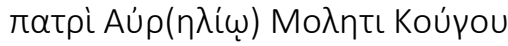

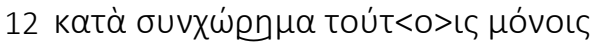

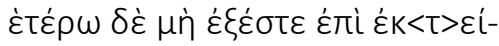

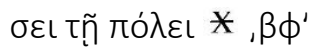

"Ben Kougas'ın torunu, Moles'in ise oğlu M(arcus) Aurelius Kamoas. Bu lahdi kendime, eşim Moles kızı Aurelia Orematis'e, kızım Aurelia Tyida'ya, ölmüş olan erkek kardeşim Aurelius Kougas'a, onun ve kendi çocuklarımla onların eşlerine ve torunlarına, annem Moles kızı Aurelia Nagis ile ölmüş olan babam Kougas oğlu Moles'e yaptırdım. Iznim uyarınca sadece bunların (gömülme) hakkı vardır, (bunlar dışında) başka kimsenin izni yoktur. Aksi takdirde kent kasasına 2500 denaria ödeyecektir".

Marcus Aurelius Kamoas: Lahdi yaptıran kişidir. Babası Moles, Dedesi Kougas'tır. Mezar sahibinin taşıdığı gibi Aurelius gens ismi dolayısıyla söz konusu lahdin en erken MS 212 yılı itibariyle yaptırıldığı söylenebilir. Kamoas ismi daha önceden bilinen bir isim değildir.

Aurelia Orematis: Babası Moles, Kocası Marcus Aurelius Kamoas'tır. Orematis ismi de ilk olarak belgelenmektedir, fakat bölgede - $\mu \alpha t ı$ ile sonlanan kadın isimleri bilinmektedir ${ }^{71}$.

Aurelia Tyida: Marcus Aurelius Kamoas'ın kızıdır ve önünde çocuk büstü vardır. Phaselis civarında buradaki isim dışında "Tuv" veya "tuı" köküne dayanan iki isim tespit edilmiştir. Bunlardan ilki Imparator Hadrian'ın Phaselis ziyareti hazırlıklarında önemli rol oynayan ve Tetragonal

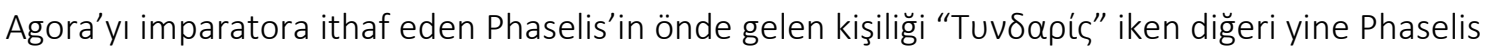

69 Tabula ansata'nın tanımına ilişkin ayrıca bk. Koch 2001, 28 vd.; Tekçam 2007, 216.

70 Lahdin yazıtını çeviren Edebiyat Fakültesi, Eskiçağ Dilleri ve Kültürleri Bölümü Öğretim Üyesi Doç. Dr. Nihal Tüner Önen'e çok teşekkür ederiz.

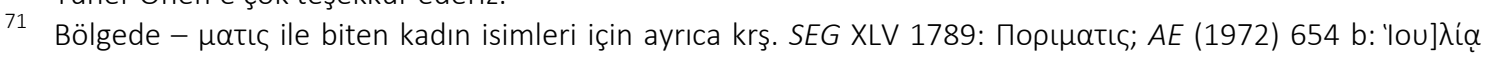
$\mathrm{M \alpha}[\tau \iota \varsigma]$... etc. 
teritoryumu içerisinde konumlanan Üçoluk/Kırtepe mevkiinde bulunan bir lahit mezar üzerinde geçen Tuıv $\delta \alpha[\rho] \alpha$ ismidir $^{72}$. Yazıtta Tyida'nın Kamoas'ın kızı olduğu açıkça verilmesine rağmen hemen arkasından genetivus causus'unda verilen Kougas'ın (Koúyou) yanlışlıkla yazılmış olması yüksek bir ihtimaldir.

Aurelius Kougas: Marcus Aurelius Kamoas'ın ölmüş olan erkek kardeşidir. Dedesi Kougas'ın adını taşıdığına göre Anadolu'da yakın geçmişe kadar süren bir gelenek olan ilk çocuğa genelde dedenin adının verilmesine benzer bir durumu o dönem için de düşünmek gerekir. Durum böyle ise önce doğmuştur ve Marcus Aurelius Kamoas'ın ağabeyidir? Ölmüş dediğine göre babasından sonra olasılıkla lahdi ikinci defa bu kullanmış olabilir. Bu isimden hemen sonra çocuklardan ve torunlardan bahsettiğine göre ve de çocuk büstü hemen yeğeninin önünde ve yakınında olduğuna göre Marcus Aurelius Kamoas'ın solundaki kızı Aurelia Tyida olur ve bunun yanında en sağdaki erkek de büyük kardeşi Aurelius Kougas olmalıdır. Kougas ismi Phaselis'te MS III. yüzyıla tarihlendirilen bir yazıt üzerinden tanınmaktadır ${ }^{73}$.

Aurelia Nagis: Marcus Aurelius Kamoas'ın annesidir. Bu kadının da babasının adı Moles'tir. Bu durumda Marcus Aurelius Kamoas'ın baba tarafından dedesi Kougas olurken anne tarafından dedesi Moles olur. Bu Moles, Marcus Aurelius Kamoas'ın babası olmayıp, kayınpederi Moles olmalıdır. Yani Moles adında iki kişi dünür olmuşlardır. Her iki Moles'in ayrı kişiler oldukları isim-

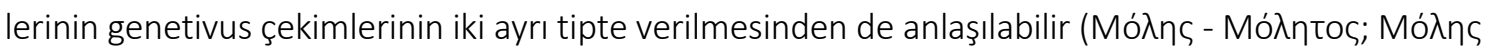
- Moגeouৎ).

Moles: Marcus Aurelius Kamoas'ın babası, Kougas'ın oğlu ve Aurelia Nagis'in kocasıdır. Kayınpederinin adı Moles'tir. Ölmüş dediğine göre lahdi ilk bu kişi kullanmış olabilir. Ayrıca Moles, yerli bir isim olup, Phaselis teritoryumunda önceki çalışmalarda 6 farklı kişide belgelenmiştir ${ }^{74}$. Bu lahit üzerinde de 3 farklı Moles olduğu anlaşılmaktadır. Böylece bu lahitle birlikte günümüze kadar toplam 9 farklı kişide tespit edilmiş olup, dolayısıyla Moles isminin o dönem bölgede yaygın olduğu anlaşılmaktadır.

Bunun dışında yazıt yazılırken Marcus Aurelius Kamoas'ın babası Moles ile kardeşi (ağabeyi?) Aurelius Kougas ölmüşlerdir ve naaşları lahde bırakılmış olmalıdır. Öyleyse Marcus Aurelius Kamoas, eşi Aurelia Orematis, kızı Aurelia Tyida ve annesi Aurelia Nagis en azından tabula ansata yazılırken hayatta olmalıdır.

Bu durumda en sağdan sola doğru kardeşi Aurelius Kougas, kızı Aurelia Tyida, Marcus Aurelius Kamoas, eşi Aurelia Orematis, annesi Aurelia Nagis ve babası Moles olur (Fig. 21). Ayrıca lahdin kapağında iki çiftin varlığı anlaşılmakla beraber lahit teknesi ön yüz sağ tarafta tondo içerisindekilerin mezar sahibi Marcus Aurelius Kamoas ile eşi Aurelia Orematis, sol tondo içindekilerin ise babası Moles ile annesi Aurelia Nagis olması beklenir (Fig. 8).

\footnotetext{
72 Tyndaris ismi için bk. Tüner Önen 2015, 62; Tyindara için bk. Tüner Önen et al. 2017, 358.

73 Adak et al. 2005, 8 vd.; Tüner Önen 2015, 44 dn. 30.

74 Ormerod - Robinson 1914, 32 nr. 48-49; Tüner Önen et al. 2017, 357.
} 


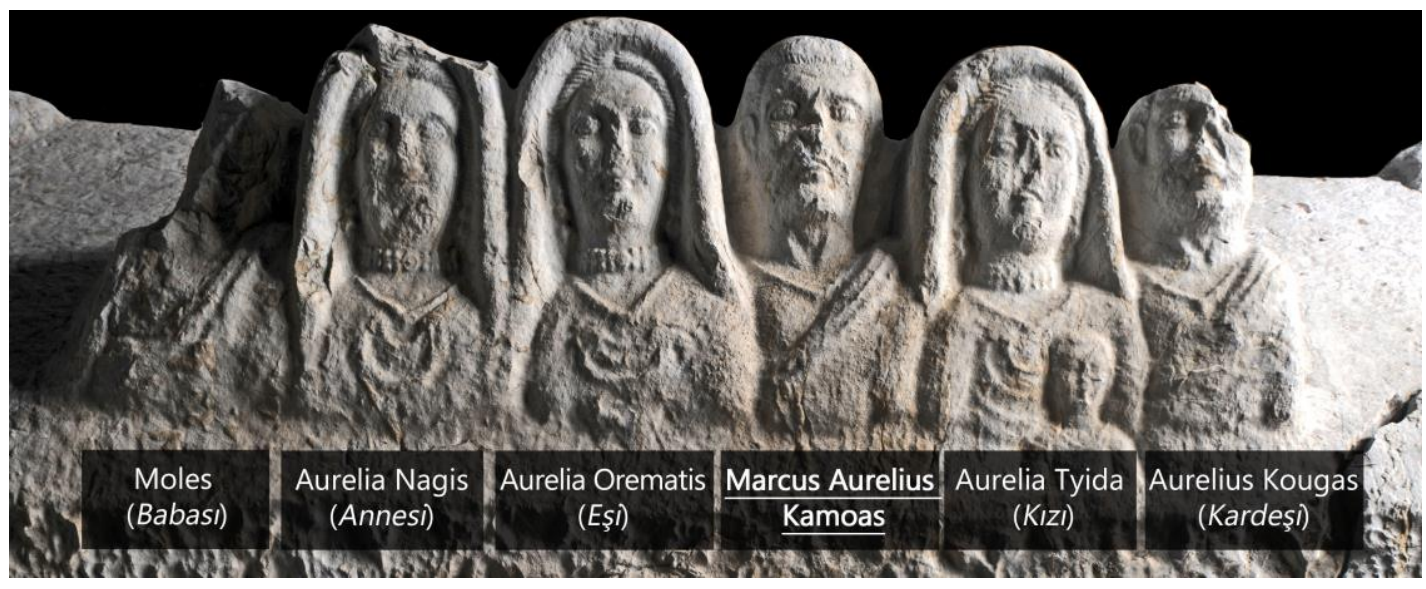

Fig. 21. Aile bireyleri

Hisarçandır Lahdi yazıından mezar sahibi Marcus Aurelius Kamoas ve ailesinin kimliğine ilişkin önemli bilgiler elde edilmekle beraber mezar cezasının kent kasasına ödeneceği de anlaşılmakta-

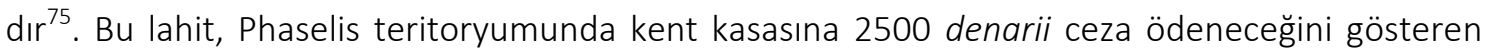
belge niteliğinde olması bakımından ikinci bir örnektir ${ }^{76}$. Ayrıca zengin kompozisyona sahip böyle bir lahit, sahibi Marcus Aurelius Kamoas'ın varlıklı bir insan olduğunu göstermektedir ${ }^{77}$.

$$
\begin{array}{ccc}
\text { Kougas (Baba Tarafindan Dedesi) } & \text { Moles (Anne Tarafindan Dedesi) } \\
\text { I } & \text { I } & \\
\text { Moles (Babası) - Aurelia Nagis (Annesi) } & \text { Moles (Kayınpederi) }
\end{array}
$$

Aurelius Kougas (Kardeşi) Marcus Aurelius Kamoas - Aurelia Orematis (Eşi)

I

\section{Aurelia Tyida (Kızı)}

\section{Tarihlendirme}

Hisarçandır Lahdi Roma Imparatorluk Dönemi'ne aittir. Genel kompozisyonu düşünüldüğünde bölgedeki benzer tipoloji ve ikonografiye sahip lahitler MS II. veya III. yüzyıla tarihlenmektedir. Bununla beraber lahdin yazıt harflerinin boyu 0.028-0.030 $\mathrm{m}$ arasında değişmektedir ve harf karakterleriyle MS III. yüzyıla tarihlenebilir ${ }^{78}$. Nitekim mezar sahibinin taşıdığı Aurelius gens ismi ile yazıtı, lahdin en azından MS 212 sonrası olduğunu gösterir ${ }^{79}$. Çünkü İmparator Caracalla MS 212 yılında çıkardığı "Constitutio Antoniniana" isimli yasa ile Roma İmparatorluğu'nda yaşayan herkese vatandaşlık hakkı vermiş ve imparatoru onurlandırmak amacıyla vatandaşlar kendi

75 Mezar cezaları için kullanımı yoğun olan kasalar; Demos, Polis, Fiscus, Hierotaton Tameion, Tapınak, Gerousia ve Tameion'dur. Kullanımı daha az olan kasalar ise Patris, özel şahıs, Lykia Birliği, Peripolion ve Kome'dir. Detaylıca bk. Avcu 2014, 22-35; Phaselis'te mezar cezaları 500-1000 denarii arasında değişmekle beraber Hierotatos Tameion (En Kutsal Kasa), Hierotatos Fiscus (En Kutsal Fiscus), Glykutates Patris (En Tatlı Vatan) kasaları yetkilidir, bk. Blackman 1981 147-149 nr. 6-7, 9; Tüner Önen et al. 2017, 354.

76 Tüner Önen et al. 2017, 354.

77 Roma Dönemi'nde statü sahibi vatandaşlar servetleriyle orantılı şekillenen lahitlere defnedilmektedir. Gürel 2017, 566.

78 Tüner Önen et al. 2017, 349, 353 fig. 13.

79 Tüner Önen et al. 2017, 353. 
isimlerinin başına "Marcus", "Aurelius" veya "Aurelia" gibi ön adlar (praenomen) almışlardır ${ }^{80}$. Bu bağlamda lahit her durumda MS III. yüzyıl olmakla birlikte mutlaka MS 212 yılından sonradır. Buna ek olarak kapak üzerindeki iki erkekte görülen saç ve sakal stili ile lahit teknesinin sağ tondosu içindeki kadının saç yapısı MS III. yüzyıl ortalarının modasını yakalayıp yansıttığından Hisarçandır Marcus Aurelius Kamoas Lahdi MS 250 civarına tarihlenebilir.

\section{Sonuç}

Kireçtaşı üzerine oyulmuş yerel iş̧̧ilikli kırsal yaşam konulu Hisarçandır Marcus Aurelius Kamoas Lahdi, son derece zengin bir kompozisyona sahiptir. Dar yüzlerinde bulunan kalkan ve mızrak betimlemeleriyle Pisidia geleneğini yansıtmaktadır. Mezar geleneğiyle bağlantılı olarak lahdin üzerindeki figür ve bezemeler bir anda ortaya çıkmış olamayacağından evveliyatı derinlemesine incelenmeye çalışımıştır. Lahit ön yüzde simetrik verilen hem kaplan avı hem de aslan-boğa mücadelesinin ölümü yenme anlamına geldiği ve ayrıca düşmana galip gelmeyi niteleyen bir zafer sahnesi olduğu anlaşımaktadır. Lahdin alt tarafındaki frizin merkezindeki karşııklı duran iki aslanın arasındaki kraterden çıkan bitki, hayat ağacını temsil eder. Hayat ağacı, hayat ve ölüm arasındaki döngünün bir işareti olarak şansı, bereketi ve doğurganlığı simgelemenin yanında öldükten sonra dirilişi sembolize etmektedir. Hayat ağacı sahnesinin sağ ve solundaki sıralı hayvanlar frizi ise alanı dolduran bir süsleme unsuru olabileceği gibi mezar koruyucusu anlamında yapılmış da olabilir. Üzerindeki özellikle kaplan avı, aslan-boğa mücadelesi, hayat ağacı ve hayvanlar sırası gibi gösterimlerle lahdin yapıldığı dönemden asırlarca öncesine giden bir geleneğin devamcısı ve yaratısı olduğu anlaşılmıştır. Bir başka ifadeyle Roma İmparatorluğu'nun altın çağına ait bir lahit de olsa, Roma'nın en az yüzyıllarca öncesinde şekillenen mezar geleneği bağlamındaki düşüncelerin bir yansımasıdır ve geçmişten bağımsız değildir.

Hisarçandır Lahdi'nde asma-üzüm bezemesi Dionysos dünyasıyla bağlantılı olabilir, bolluk ve bereketi simgeler. Ancak burada asma-üzümün benzer kullanılışıla hayat ağacı gibi öldükten sonra dirilişi simgelediği ve bu nedenle lahitlerde tercih edildiği düşünülebilir. Ayrıca lahdin yakınında çiftlik evi ve işlik kalıntıları ile asma-üzüm bezemesi göz önüne alındığında, bu lahit ve bölgedeki diğer benzer ikonografideki lahitler, mezar sahibinin yaşadığı üzüm bağlarıyla dolu kırsalı ve belki tarımla uğraşan kimliğiyle birarada gösteriyor olmalıdır. Bu bağlamda kırsal yaşam konulu yerel üretim bu tip lahitler dönemin bölgedeki tarımsal faaliyetlerine tanıklık etmesi ve kırsal yerleşmelere ilişkin kayıtları göstermesi bakımından çok önemlidir.

Hisarçandır Lahdi'nin bulunduğu dağlık bölge civarında; Lykia, Pamphylia ve Pisidia sınırında, çok zengin içerikli, adeta kendine özgü lahit örnekleri tespit edilmiştir. Bu zenginliğin kökeninde sözü edilen kültür bölgelerinin geçiş sahasında bulunmalarının etken olduğu söylenebilir. Ayrıca benzer ikonografiye sahip lahitlerin durumu düşünüldüğünde döneminin lahit geleneğine hâkim olup, siparişler üzerine lahitler yapan gezici yerel ustaların var olduğunu söylemek mümkündür. Söz konusu topografyada bu kadar birbirine benzeyen stil ve ikonografiye sahip yerel lahitlerin sanat birlikteliği ancak gezici yerel lahit ustalarıyla sağlanmış olmalıdır. Lahit ön yüz merkezindeki tabula ansata'dan anlaşıldığına göre mezarın sahibi Marcus Aurelius Kamoas'tır ve kapaktaki yüksek kabartma büstlerle adeta bir aile fotoğrafı verilmiştir. Yazıttan yola çıkarak aile bireylerinin kimliğine yönelik öneriler getirilmiştir. Yerel iş̧̧ilikli olmasına rağmen diğer özelliklerinin yanı sıra yazıtı ve dönemini yansıtan büstlerdeki portre özellikleri lahdin MS 250 civarına tarihlenmesinde yardımcı olmuştur. Sonuç itibariyle lahit zengin kompozisyonuyla bölgedeki yerel üretim lahitlerin anlaşılması bağlamında önemli veriler sunmuş ünik bir eserdir.

80

Özdizbay 2002, 494, dn. 45; Özer 2013 (b), 463. 


\section{BIBLIYYOGRFYA}

Abay 2016

Adak et al. 2005

$\mathrm{AE}$

Akalın 2008

Akçay 2016

Akurgal 1995

Akurgal 1998

Arnold 1995

Arslan et al. 2013

Avcu 2014

Belli 1980

Bielefeld 1997

Blackman 1981

Bodzek 2014

Borchhdart 1976

Cambi 2010

Carpenter 2002

Cohen 2010

Cömert 2014

Çelgin 1990

Çekilmez 2015

Çevik 1999

Çevik 2008
N. Abay, "Konya Koyunoğlu Müzesinde Roma Dönemine Ait íki Stel”. Selçuk Üniversitesi Edebiyat Fakültesi Dergisi (SEFAD) 35 (2016) 329-342.

M. Adak, N. Tüner Önen - S. Şahin, "Neue Inschriften Aus Phaselis I". Gephyra 2 (2005) 1-20.

L'Année Épigraphique 1970-1999.

E. Akalın, Termessos Teritoriumunda Neapolis'e Bağlı Bir Yerleşim: Kartınpınarı. Yayımlanmamış Yüksek Lisans Tezi, Akdeniz Üniversitesi Sosyal Bilimler Enstitüsü. Antalya 2008.

A. Akçay, "Epigrafi Araştırmalarında Yeni Bir Belgeleme ve Analiz Metodu Olarak RTI”. MJH VI/2 (2016) 1-16.

E. Akurgal, Hatti ve Hitit Uygarlıkları. İzmir 1995.

E. Akurgal, Anadolu Kültür Tarihi. Ankara 1998.

D. Arnold, An Egyptian Bestiary. The Metropolitan Museum of Art Bulletin, JSTOR, (1995).

M. Arslan, K. Demirtaş - N. Tüner Önen, "Phaselis ve Teritoryumu Yüzey Araştırması 2012". Anmed 11 (2013) 224-229.

F. Avcu, Lykia Bölgesi Yazıtlarında Cezalar ve Ceza Tahsil Kurumları. Yayımlanmamış Yüksek Lisans Tezi, Akdeniz Üniversitesi Sosyal Bilimler Enstitüsü, Antalya 2014.

O. Belli, "Urartular'da Hayat Ağacı İnancı". Anadolu Araştırmaları VIII (1980) 237-247.

D. Bielefeld, Stadtrömische Eroten-Sarkophage: Weinlese und Ernteszenen. Gebr. Mann Verlag, Berlin, 1997.

D. J. Blackman, D. J. Blackman, "The Inscriptions". Ed. J. Schäfer, Phaselis. Beiträge zur Topographie und Geschichte der Stadt und ihrer Häfen, Tübingen (1981) 138-163.

J. Bodzek, "Achaemenid Asia Minor: Coins of the Satraps and of the Great King". Şurada: Birinci Uluslararası Anadolu Para Tarihi ve Numismatik Kongresi 25-28 Şubat 2013, Antalya (2014) 59-78.

J. Borchhdart, Die Bauskulpturs des heroons von Limyra: das Grabmal des lykischen Königs Perikles. Istanbuler Forschungen 32: Gebr. Mann Verlag, Berlin, 1976.

N. Cambi, Sarkofazi Lokalne Produkcije u Rimskoj Dalmaciji (Die Sarkophage der Lokalen Werkstätten im Römischen Dalmatien). Književni Krug, Split, 2010.

T. H. Carpenter, Antik Yunan'da Sanat ve Mitoloji. Çev. B. M. Bensen Ünlüoğlu. İstanbul 2002.

A. Cohen, Art in the Area of Alexander the Great: Paradigms of Manhood and Their Cultural Traditions. Cambridge, 2010.

B. Cömert, Mitoloji ve Ikonografi. Ankara 2014.

A. V. Çelgin, Termessos Antik Kenti Nekropol'leri. Yayımlanmamış Doktora Tezi. İstanbul Üniversitesi, Sosyal Bilimler Enstitüsü, İstanbul 1990.

M. Çekilmez, "2008 Yılı Tralleis Kazısı Koroplastik Buluntuları". Cedrus III (2015) 51-66.

N. Çevik, "Hayat Ağacı'nın Urartu Kült Törenlerindeki Yeri ve Kullanım Biçimi". Anadolu Araştırmaları 15 (1999) 335-367.

N. Çevik, "Northeast Lycia. The New Evidence - Result from the past ten years from the Bey Mountains Surface Surveys". Adalya XI (2008) 189-233. 
196

Çevik 2015

Dökü 2008

Durukan 2007

Erhat 1972

Frel - Morgan 1987

Fuchs 1979

Grimal 1997

Gürel 2016

Gürel 2017

Hamdi Bey - Reinach 1892

Heckel - Tritle 2009

Herdejürgen 1996

Higgins 1980

Huskinson 2015

İdil 1981

İşkan 2002

Işık 1977

Işık 1982

Işık 1983

Işık 1993

Işık 2003

Işık 2015

Karaüzüm 2005

Kenaan-Kedar 2012

\section{Ahmet ÇELIK - Süleyman ATALAY - Ferhan BÜYÜKYÖRÜK}

N. Çevik, Lykia Kitabı. İstanbul 2015.

F. E. Dökü, Paphlagonia Bölgesi Kaya Mezarları ve Kaya Tapınakları. Yayımlanmamış Doktora Tezi, Akdeniz Üniversitesi, Sosyal Bilimler Enstitüsü. Antalya 2008.

M. Durukan, "Dead Cult in Olba Region During Hellenistic and Roman Periods". Anatolia Antiqua XV (2007) 147-164.

A. Erhat, Mitoloji Sözlüğü. İstanbul 1972.

J. Frel - S. K. Morgan, Roman Portraits in the J. Paul Getty Museum. 1987.

W. Fuchs, Die Sculptur der Griechen. München, 1979.

P. Grimal, Mitoloji Sözlüğü: Yunan ve Roma. Çev. S. Tamgüç. İstanbul 1979.

B. Gürel, "Phaselis Batı ve Kuzeybatı Nekropolis'leri". MJH VI/2 (2016) 279297.

B. Gürel, "Yunan ve Roma'da Ölü Kültü". Yazar: T. Akçay. Libri III (2017) 561567.

. Hamdi Bey - T. Reinach, Une Nécropole Royale a Sidon. Paris, 1892.

W. Heckel - L. A. Tritle, Alexander the Great: A New History. Malden - Oxford, 2009.

H. Herdejürgen, Stadrömische und Italische Girlandensarkophage: Die Sarkophage des Ersten und Zweiten Jahrhunderts. Gebr. Mann Verlag, Berlin, 1996.

R. A. Higgins, Greek and Roman Jewellery. University of California Press, Berkeley and Los Angeles 1980.

J. Huskinson, Roman Strigillated Sarcophagi: Art and Social History. Oxford Universty Press, Oxford, 2015.

V. İdil, Likya Lahitleri. Doçentlik Tezi. Ankara Üniversitesi, Dil ve TarihCoğrafya Fakültesi, Ankara 1981.

H. İşkan, "Zwei Privatporträts aus Patara". Jahrbuch Des Deutschen Archäologischen Instituts 117 (2002) 251-282.

F. Işık, "Zur Datierung des verschollenen Girlandensarcophags aus Alaşehir". Archaeologischer Anzeiger (1977) 380-383.

F. Işık, "Kleinasiatische Girlandensarkophage mit Pilaster-oder Säulenarchitektur". Jahresheften des Österreichischen Archäologischen Institutes 53 (1982) 30-146.

F. Işık, "Das Kuppelgrab von Halifet Alp Gazi in Amasya und sein widerventerer römischer Girlandensarkophag". Marburger Winkelmann Programm (1983) 247-284.

F. Işık, "Zur Kontinuitatsfrage der Kleinasiatischen Girlandensarcophage wahrend des Hellenismus und ober frühen Kaiserzeit". Grabekunst der römischen Kaizerzeit, (1993) 9-21.

F. Işık, "Karanlık Dönem'in Aydınlığı ve Frig Sanatının "Anadoluluğu” Üzerine". Anadolu/Anatolia 24 (2003) 19-33.

F. Işık, "Arkeolojik Bulgular Işığında Milyas”. Anadolu/Anatolia 41 (2015) 187237.

G. Karaüzüm, Doğu Dağlık Kilikya (Olba) Bölgesi Lahitleri. Yayımlanmamış Yüksek Lisans Tezi, Mersin Üniversitesi, Sosyal Bilimler Enstitüsü, Mersin, 2005.

N. Kenaan-Kedar, "Sculpted Palmyrian Funerary Female Portraits with Extensive Jewelry Sets: A Revisionist Reading of Their Meanings and Impact". Şurada: Art History 2012 The Future Is Now. Studies in Honor of Vladimir Peter Goss Celebrating his 70 Birthday (2012) 108-120. 
Kızgut et al. 2009

Koch 2001

Koch 2010

Koch - Sichterman 1982

Köroğlu 1996

Kranz 1984

Kranz 1999

Küsmez 2009

Lanckoroński 1890

Lanckoroński 1892

Malzbender et al. 2001

Marshall 1911

McCann 1978

Mudge et al. 2006

Ogden 1991

Ormerod - Robinson 1914

Oliver 1966

Otlu 2014

Öz 2005

Özdilek 2006

Özdilek - Çevik 2009
I. Kızgut, S. Bulut - N. Çevik, "An East Lycian City: Idebessos". Adalya XII (2009) 145-172.

G. Koch, Roma imparatorluk Dönemi Lahitleri. İstanbul 2001.

G. Koch, Türkiye'deki Roma Imparatorluk Dönemi Lahitleri (Sarkophage der römischen Kaiserzeit in der Türkei). Çev. B. Varkıvanç. Antalya 2010.

G. Koch - Sichterman, Römische Sarkophage, C. H. Beck'sche Verlagsbuchhandlung. München, 1982.

H. Köroğlu, Frigler'de Hayat Ağacı Inancı. Yayımlanmamış Yüksek Lisans Tezi, Atatürk Üniversitesi Sosyal Bilimler Enstitüsü, Erzurum 1996.

P. Kranz, Jahreszeiten-Sarkophage: Etwicklung und Ikonographie des Motivs der Vier Jahreszeiten Auf Kaiserzeitlichen Sarkophagen und Sarkophagdeckeln. Gebr. Mann Verlag, Berlin, (1984).

P. Kranz, Stadtrömische Eroten-Sarkophage: Dionysische Themen, Mit Ausnahme der Weinlese und Ernteszenen. Gebr. Mann Verlag. Berlin 1999.

P. Küsmez, Başlangııından MÖ 2.binin Sonuna Kadar Anadolu Tasvir Sanatında Av Sahneleri. Yayımlanmamış Yüksek Lisans Tezi, Selçuk Üniversitesi, Sosyal Bilimler Enstitüsü, Konya, 2009.

K. G. Lanckoroński, Städte Pamphyliens und Pisidiens. Pamphylien Band I, Wien 1890.

K. G. Lanckoroński, Städte Pamphyliens und Pisidiens. Pisidien Band II. Wien 1892.

T. Malzbender, D. Gelb - H. Wolters. "Polynomial Texture Maps". $28^{\text {th }}$ Annual Conference on Computer Graphics and Interactive Techniques (SIGGRAPH'01). New York (2001) 519-528. Doi: 10.1145/ 383259.383320.

F. H. Marshall, Catalogue of the Jewellery, Greek, Etruscan, and Roman, in the Departments of Antiquities. British Museum, London 1911.

A. M. McCann, Roman Sarcophagi in The Metropolitan Museum of Art. New York, 1978.

M. Mudge, T. Malzbender, C. Schroer - L. Marlin. "New Reflection Transformation Imaging Methods for Rock Art and Multiple-Viewpoint Display". Eds. M. Ioannides, D. Arnold, F. Niccolucci - K. Mania, The $7^{\text {th }}$ International Symposium on Virtual Reality, Archaeology and Cultural Heritage (VAST'06), Eurographics Association, Nicosia, Cyprus (2006) 195-202.

J. Ogden, Ancient Jewellery. University of California Press, Berkeley and Los Angeles 1991.

H. A. Ormerod - E. S. G. Robinson, "Inscriptions from Lycia". JHS 34 (1994) 1-35.

A. Oliver, "Greek, Roman, and Etruscan Jewelery". The Metropolitan Museum of Art Bulletin 24/9 (1966) 269-284.

Ö. Otlu, Arkeolojik ve Filolojik Belgeler Işığında MÖ 2. Binde Anadolu'da Geyik Tasvirleri. Yayımlanmamış Yüksek Lisans Tezi, Gazi Üniversitesi, Sosyal Bilimler Enstitüsü. Ankara 2014.

E. Öz, Asur Ticaret Kolonileri Döneminde Anadolu'nun Etnik ve Sosyal Yapısı. Yayımlanmamış Yüksek Lisans Tezi, Ankara Üniversitesi, Sosyal Bilimler Enstitüsü. Ankara 2005.

B. Özdilek, Neapolis Nekropolü. Yayımlanmamış Yüksek Lisans Tezi, Akdeniz Üniversitesi, Sosyal Bilimler Enstitüsü. Antalya 2006.

B. Özdilek - N. Çevik, New Discoveries in Rural North East Lycia: Scenes of Daily Life on Roman Rural Sarcophagi". Şurada: Soma 2007, BAR (2009) 284290. 
Özdizbay 2002

Özer 2013 (a)

Özer 2013 (b)

Özer 2014

Özsait et al. 2009

Özüdoğru 2013

Öztürk 2003

Sande 1987

SEG

Strocka 1996

Strootman 2014

Şahan 2009

Şimşek 1998

Tekçam 2007

Texier 1865

Turak 2005

Turak 2012

Tüner Önen 2008

Tüner Önen 2015

Tüner Önen et al. 2017

Wood 1987

Yıldırım 2003

\section{Ahmet ÇELIK - Süleyman ATALAY - Ferhan BÜYÜKYÖRÜK}

A. Özdizbay, "Perge Batı Nekropolisi'nden Bir Mezar Yazıtı". Anadolu Araştırmaları (2002) 483-507.

E. Özer, "Olympos Antik Kentinde Bir Grup Rölyefli Lahit". Ed. M. Tekocak. Levent Zoroğlu'na Armağan (2013) 479-498.

E. Özer, "Mezar Yazıtları ile Olympos". Uluslararası Sosyal Araştırmalar Dergisi 6/27 (2013) 460-468.

E. Özer, "A Typological Suggestion Concerning Hellenistic and Roman Lycian Sarcophagi". Cedrus II (2014) 75-87.

M. Özsait - G. Labarre - N. Özsait, "Timbriada et Tynada (Pisidie)". Adalya XII (2009) 197-219.

Ş. Özüdoğru, "Arkaik Dönem'den Bir Likya Dynast Mezarı Üzerindeki “Aslan Öldürme" Sahnesi: Anlamı ve Kökeni Üzerine Değerlendirmeler". Anadolu /Anatolia 39 (2013) 69-86.

A. Öztürk, Batı Dağlık Kilikya Bölgesi Kaya Mezarları. Yayımlanmamış Yüksek Lisans Tezi, Pamukkale Üniversitesi, Sosyal Bilimler Enstitüsü, Denizli, 2003.

S. Sande, "Two Female Portraits from the Early Gallienic Period". Ancient Portraits in the J. Paul Getty Museum, Volume 1, California (1987) 137-142.

Supplementum Epigraphicum Graecum.

V. M. Strocka, "Datierungkriterien kleinasiatischer Girlandensarkophage". Archaeologischer Anzeiger 3 (1996) 455-473.

R. Strootman, Courts and Elites in the Hellenistic Empires: The Near East After the Achaemenids, c. 330 to 30 BCE. Edinburgh, 2014.

M. M. Şahan, Batı Anadolu'da Podyum Mimarisinin Oluşumu. Yayımlanmamış Yüksek Lisans Tezi, Dokuz Eylül Üniversitesi, Sosyal Bilimler Enstitüsü, İzmir 2009.

C. Şimşek, "Laodikya Ana Küme Girlandlı Lahitleri". Arkeoloji ve Sanat Dergisi 85 (1998) 2-25.

T. Tekçam, Arkeoloji Sözlüğü. İstanbul 2007.

C. Texier, The Principial Ruins of Asia Minor. London 1865.

Ö. Turak, Pamphylia Bölgesinde Bulunan Attika Tipi Lahitler. Yayımlanmamış Yüksek Lisans Tezi, İstanbul Üniversitesi, Sosyal Bilimler Enstitüsü, İstanbul 2005.

Ö. Turak, "Perge'den Attika Tipinde Dionysiak Bir Lahit". Adalya XV (2012) 223-247.

N. Tüner Önen, Phaselis Antik Kenti ve Teritoryumu. Yayınlanmamış Doktora Tezi, Akdeniz Üniversitesi. Antalya 2008.

N. Tüner Önen "Annäherungen zur Geschichte der Stadt Phaselis auf onomastischer: Ein Studium der Namen aus Phaselis und ihrem Territorium". Phaselis I (2015) 39-67. DOI: 10.18367/Pha.15003

N. Tüner Önen, B. Gürel - A. Akçay, "Phaselis Teritoryumunda Tespit Edilen Lahitlerin RTI Metodu Işığında Arkeolojik ve Epigrafik İncelemeleri". Phaselis III (2017) 343-369. DOI: 10.18367/Pha.17021

S. Wood, "Child-Emperors and Heirs to Power in Third-Century Portraiture". Ancient Portraits in the J. Paul Getty Museum, Volume 1, California (1987) 115-136.

S. Yıldırım, "Aslan-Boğa Mücadelesi Kompozisyonu". Ankara Üniversitesi Dil ve Tarih Coğrafya Fakültesi Dergisi 43-2 (2003) 1-18. 